\title{
Energie en democratie: democratische invloed op regionale energiestrategieën en andere complexe besluitvormingsprocessen ${ }^{*}$
}

\author{
Marcel Boogers ${ }^{* *}$
}

\section{Inleiding}

Besturen is een werkwoord en meervoudsvorm tegelijkertijd. De combinatie van beide kenmerkt de huidige bestuurlijke praktijk, die zich voltrekt in een samenspel tussen gemeenten, provincies, waterschappen, departementen en soms Europese instellingen. Besturen besturen tegenwoordig steeds meer samen. Ook belangenorganisaties, bedrijven, instellingen en bewoners doen vaak mee. Dit samenspel biedt flexibiliteit en slagkracht bij de aanpak van belangrijke vraagstukken, maar veroorzaakt ook problemen die deze voordelen gemakkelijk teniet kunnen doen. De kern hiervan is dat besturen samen besturen, terwijl democratische sturing, controle en verantwoording zich beperken tot één enkel bestuur. Dit raakt het functioneren van gemeenteraden, provinciale staten en andere vertegenwoordigende organen, maar het heeft ook gevolgen voor de slagvaardigheid van het bestuur.

Dit probleem speelt momenteel heel acuut bij de totstandkoming van regionale energiestrategieën, in bestuurlijk jargon meestal afgekort tot RES('en). In dertig regio's worden gezamenlijke afspraken gemaakt over duurzame energie, terwijl de democratische verantwoording hierover plaatsvindt in afzonderlijke gemeenteraden, provinciale staten en het algemeen bestuur van het waterschap. In alle regio's wordt daarom geworsteld met de vraag hoe volksvertegenwoordigers meer grip kunnen krijgen op de besluitvorming over de RES. Ook wordt nagedacht over de manier waarop maatschappelijk draagvlak voor de RES kan worden georganiseerd. De belangen die op het spel staan zijn immers groot: het gaat om de plaatsing van windmolens, de aanleg van zonneparken of de verduurzaming van corporatiewoningen.

In dit artikel worden de democratische problemen van meervoudig besturen nader geduid, met een focus op het besluitvormingsproces rond de RES. Eerst wordt ingegaan op de risico's die deze democratische problemen met zich brengen voor het democratisch draagvlak en voor de kwaliteit en snelheid van de besluitvorming. Hierna worden deze problemen - en de mogelijke aanpak hiervan -

* Dit artikel is een grondige bewerking van het essay Energie en democratie dat de auteur voor het ministerie van Binnenlandse Zaken en Koninkrijksrelaties en het nationaal programma 'Regionale Energiestrategieën' schreef (Boogers, 2019).

** Prof. dr. Marcel Boogers is hoogleraar innovatie en regionaal bestuur aan de Universiteit Twente en senior adviseur bij BMC. In zijn onderzoek en advies richt hij zich op de kwaliteit van besluitvormingsprocessen in interbestuurlijke verhoudingen. 
besproken aan de hand van drie democratievisies: de representatieve democratie, de pluralistische polderdemocratie en de participatieve democratie.

\section{RES: meervoudig besturen en meervoudige democratie}

Een RES is een regionale uitwerking van het nationale energieakkoord waarin gemeenten, provincie en waterschap in dertig regio's afspraken maken over duurzame energie- en warmtevoorziening. In een RES worden het aanbod van, de vraag naar en de geplande infrastructuur voor warmte in een regio vastgelegd. Verder dient de RES uitspraken te doen over plaatsen waar grootschalig duurzame elektriciteit kan worden opgewekt en hoe de hiervoor benodigde infrastructuur en opslagcapaciteit worden georganiseerd. Decentrale overheden doen dat samen met regionale sleutelspelers, zoals netbeheerders en energiecoöperaties. Verder dient ook de participatie van belanghebbenden te worden georganiseerd, zoals inwoners, bedrijven, woningcorporaties en milieuorganisaties. De besluitvorming voor de RES is in alle regio's inmiddels gestart, in sommige regio's is het RES-proces zelfs al nagenoeg afgerond. De conceptversie van de RES dient in juni 2020 gereed te zijn, waarna de definitieve RES - na toetsing door het Planbureau voor de Leefomgeving en het nationaal programma 'Regionale Energiestrategieën' - in maart 2021 kan worden vastgesteld (Klimaatakkoord, 2019). Ook zonder de coronacrisis is dit een krappe deadline. In veel regio's bleek het lastig of zelfs onmogelijk om belanghebbenden en vertegenwoordigende organen op deze korte termijn een bijdrage aan de besluitvorming te laten leveren. Afzonderlijke gemeenteraden, provinciale staten en het algemeen bestuur van het waterschap dienen de definitieve RES uiteindelijk in maart 2021 vast te stellen, maar of ze ook eerder een inbreng kunnen leveren is voor veel regio's maar zeer de vraag. De gedachte is dat zij uitgebreider aan bod kunnen komen in een volgende RES, waarin nieuwe en meer gedetailleerde afspraken worden gemaakt over energietransitie.

\section{Risico's}

Het RES-proces is een schoolvoorbeeld van meervoudig besturen: binnen én tussen bestuurslagen, samen met bedrijven, instellingen, organisaties en inwoners. De bestuurlijke en democratische problemen die inherent zijn aan meervoudig besturen, brengen ook voor de totstandkoming van de RES allerlei risico's met zich. Deze zijn terug te voeren op spanningen tussen het meervoudig besturen en de enkelvoudige democratie (Olsson, 2003).

\section{Draagvlak}

Het eerste probleem is dat gemeenteraden, provinciale staten en het algemeen bestuur van het waterschap weinig tot geen rechtstreekse invloed hebben op de uitkomsten van het RES-proces. Het is daardoor twijfelachtig of de keuzes die bij de RES in het geding zijn op een gezaghebbende manier tegen elkaar kunnen worden afgewogen (Boogers, 2018). Het draagvlak voor de uiteindelijke RES is zo bezien op voorhand onzeker. 


\section{Regionale strategie, lokale belangen}

Dat het zwaartepunt van de democratische sturing en controle bij de verschillende overheden van elke regio ligt, levert nog een tweede probleem op. Individuele gemeenten, de provincie en het waterschap hebben hierdoor een sterker democratisch mandaat dan de gezamenlijke onderhandelaars, waardoor hun individuele belangen het gezamenlijke besluitvormingsproces gemakkelijk kunnen gaan overheersen (Boogers, 2016). Bij de zoektocht naar een geschikte locatie voor windmolens zal dan meer worden gelet op wat gemeenten hierover in hun collegeprogramma hebben afgesproken en zal er minder aandacht zijn voor wat voor de regio als geheel de beste keuze is.

\section{Depolitiseren en polariseren}

Het laatste gevaar dat op de loer ligt is dat van depolitisering: om tot snelle en effectieve besluitvorming te komen wordt deze vaak overgelaten aan ambtenaren en andere experts. Het is echter moeilijk om maatschappelijke conflicten over energievraagstukken in goede banen te leiden als er geen openbaar politiek debat over wordt gevoerd (Mudde, 2017). De ruwe weerstanden die de aanleg van een Drents windmolenpark opriep - met zelfs bedreigingen aan het adres van ondernemers en overheden - laten zien dat dit probleem niet ondenkbeeldig is.

\section{Democratie en meervoudig bestuur: drie perspectieven}

Deze problemen en de mogelijke aanpak hiervan kunnen vanuit drie theoretische perspectieven worden beschouwd: de representatieve democratie, de pluralistische polderdemocratie en de participatieve democratie. Het eerste, meest voor de hand liggende perspectief is dat van de representatieve democratie. Zoals gezegd dient de RES te worden vastgesteld door regionale volksvertegenwoordigingen: afzonderlijke gemeenteraden, provinciale staten en het algemeen bestuur van het waterschap. Zij hebben het laatste woord, maar om hier inhoud aan te kunnen geven moeten ze niet pas op het laatst hun inbreng leveren. Het is dus zaak ze eerder bij de besluitvorming te betrekken. Een manier om dat te doen is door het instellen van gezamenlijke regiocommissies (Boogers, 2019). In een aantal regio's is al met dit model geëxperimenteerd. In deze regiocommissies komen regionale volksvertegenwoordigers tot een gezamenlijke beeld- en oordeelsvorming over duurzame energie in hun regio. De regiocommissies worden samengesteld door vertegenwoordigers van elke fractie uit de gemeenteraden, provinciale staten en het waterschap. Om te voorkomen dat lokale belangen het debat gaan overheersen en dat regionale politieke afwegingen meer centraal komen te staan, kan worden bevorderd dat de leden van de regiocommissie politieke fracties vormen. In de regio Drechtsteden - waar raadsleden al jarenlang in de Drechtraad gezamenlijk besluiten over regionale aangelegenheden - is het werken met regionale politieke fracties al heel gewoon. De uitkomst van de oordeelsvormende beraadslagingen in de regiocommissie is een gezamenlijk advies aan de gemeenteraden, provinciale staten en het algemeen bestuur van het waterschap over de uitgangspunten voor de opwekking en opslag van duurzame energie en over concept- en 
eindversie van de RES. Omdat fractiespecialisten van alle vertegenwoordigende organen zich hier al over hebben kunnen uitspreken, is de kans groot dat elke volksvertegenwoordiging het advies overneemt. Als dat niet gebeurt, moet dat in een volgende bijeenkomst van de regiocommissie worden verantwoord. In het uiterste geval, bijvoorbeeld als er op het laatst geen overeenstemming over de definitieve RES wordt bereikt, kan de provincie een knoop doorhakken.

De representatieve democratie van vertegenwoordigende organen en de gezamenlijke regiocommissie heeft als nadeel dat deze zich beperkt tot gemeenten, provincie en waterschap. Omdat de uitvoering van de RES onmogelijk is zonder medewerking van bedrijven, instellingen en belangenorganisaties, is het daarom nodig om de democratische vormgeving van het RES-proces te verrijken met elementen van de polderdemocratie. Omdat polderpartners vaak regionaal zijn georganiseerd en een meer inhoudelijke focus hebben, kunnen zij tevens voorkomen dat lokale belangentegenstellingen te zeer gaan domineren. Volgens het klimaatakkoord voorziet het RES-proces in de betrokkenheid van regionale sleutelspelers als netbeheerders en energiecoöperaties. Ook wordt het belang onderkend van bedrijven, woningbouwcorporaties, kennisinstellingen en relevante belangenorganisaties (Klimaatakkoord, 2019). Aan hen kan op verschillende manieren een rol gegeven worden bij de ambtelijke en bestuurlijke stappen in het RES-proces: ambtelijk door kennis en expertise te leveren bij het uitwerken van voorstellen, bestuurlijk door een inbreng te leveren aan de voorbereidingen op de besluitvorming en bij de uitvoering van besluiten. In veel triple-helix samengestelde regional development boards (met vertegenwoordigers van overheid, ondernemingen, onderwijs- en kennisinstellingen) is hiermee in veel regio's al ervaring opgedaan.

Omdat niet alle belangen zich even gemakkelijk laten vertegenwoordigen door de representatieve democratie en de polderdemocratie, is het goed om de democratische verankering van het RES-proces te versterken met vormen van participatieve democratie. Dat kan op verschillende manieren: inwoners kunnen in de gelegenheid worden gesteld om zich een oordeel te vormen over de stappen in het RESproces of hun kan de mogelijkheid worden geboden om hieraan zelf rechtstreeks een inbreng te leveren. Voor wat betreft dat laatste kan worden gedacht aan burgertoppen met gelote burgers. Ervaring leert dat deze vorm goede mogelijkheden biedt om debatten over politiek gevoelige of complexe onderwerpen op een evenwichtige manier te voeren én af te ronden (Setälä \& Smith, 2018). In Nederland zijn enige ervaringen opgedaan met regionale burgertoppen (Boogaard \& Michels, 2016). Steenwijkerland had de primeur met een burgertop over duurzame energie: ongeveer 300 inwoners hebben hier plannen opgesteld en uitgewerkt voor een energieneutrale gemeente. Deze plannen zijn later in de vorm van een burgerbesluit overgenomen door de gemeenteraad.

\section{Naar een juiste mix}

Vanzelfsprekend zijn er spanningen tussen de verschillende democratieperspectieven. In theorie en ook in de praktijk kan de ene zienswijze op democratische 
besluitvorming gemakkelijk de andere verdringen (Hendriks, 2012). Voorstanders van de representatieve democratie stellen dat deze uiteindelijk het meest toegankelijk is (stemmen kost minder moeite en tijd dan meepraten) en betere garanties biedt voor een zorgvuldige belangenafweging (belangenbehartigers kunnen dat beter dan belanghebbenden). Verder is de representatieve democratie staatsrechtelijk beter verankerd. Voorstanders van de polderdemocratie stellen dat de maatschappelijke belangen hierin beter tot hun recht komen (belangenorganisaties weten die beter te vertegenwoordigen dan politieke partijen) en dat maatschappelijke kennis en kunde hier beter kan worden benut (ook hiervoor zijn politieke partijen minder geëquipeerd). Verder wordt met de polderdemocratie meer recht gedaan aan de feitelijke betrokkenheid van maatschappelijke partners bij de uitvoering van beleid. Vanuit de participatieve democratie wordt geredeneerd dat dit de meest pure en zuivere vorm van democratie is waarin inwoners rechtstreeks, zonder tussenkomst van politieke partijen of belangenorganisaties, hun inbreng kunnen leveren in besluitvormingsprocessen. Verder wordt betoogd dat deze democratievorm beter meer betrokkenheid en draagvlak weet te realiseren dan de eerdergenoemde democratievormen.

Tegenover dit beeld van elkaar verdringende democratische principes kan ook worden gesteld dat ze elkaar kunnen aanvullen en versterken. Dat zou bij het RES-proces ook goed kunnen. Wettelijke kaders gebieden dat de representatieve democratie een centrale rol speelt bij de democratische verankering van de RESbesluitvorming. Gemeenteraden, provinciale staten en het algemeen bestuur van het waterschap dienen de uiteindelijke RES immers vast te stellen. Het is om meerdere redenen nodig om hun rol in het RES-proces te versterken, maar voor een betere democratische verankering dient de representatieve democratie te worden aangevuld met elementen van polderdemocratie en participatieve democratie. Hoe dat het best kan gebeuren, welke mengvorm optimaal is, zal van regio tot regio verschillen. Veel zal afhangen van de betrokken partijen en de belangen die op het spel staan. Maatwerk is geboden.

\section{Literatuur}

Boogaard, G., \& Michels, A. (red.) (2016). G1000: ervaringen met burgertoppen. Den Haag: Boom.

Boogers, M. (2016). Meer democratie tegen regionale belangen-blindheid. In: H. Pennepohl \& E. de Kluis (red.), Lokale democratie in de steigers. Leusden: ISVW, 31-40.

Boogers, M. (2018). Intergemeentelijke samenwerking: democratisch deficit, voordelen onontkoombaarheid. In: A.W. Heringa \& J.W. Schinkelshoek (red.), Een goede raad: stand van de lokale democratie na de gemeenteraadsverkiezingen van 2018. Den Haag: Boom, 34-42.

BZK (2019). Positionering van volksvertegenwoordigers in de Regionale Energie Strategie. Den Haag: BZK/DIA. www.lokale-democratie.nl/sites/default/files/2019-09/Handreiking \%20RES.pdf.

Hendriks, F. (2012). Democratie onder druk: over de uitdagingen van de stemmingendemocratie. Amsterdam: Van Gennep. 
Klimaatakkoord (2019). Regionale Energie Strategie (RES), hoofdstuk D7. www.regionaleenergiestrategie.nl/documenten/d+-klimaatakkoord+28+juni+2018/ handlerdownloadfiles.ashx?idnv=1389531.

Mudde, C. (2017). On Extremism and Democracy in Europe. Londen: Routledge

Olsson, J. (2003). Democracy paradoxes in multi-level governance: Theorizing on structural fund system research. Journal of European Public Policy, 10 (2): 283-300.

Setälä, M., \& Smith, G. (2018). Mini-publics and deliberative democracy. In: A. Bächtiger, J. Dryzek, J. Mansbridge \& M.E. Warren (red.), The Oxford Handbook of Deliberative Democracy. Oxford: Oxford University Press, 300-314. 